possible case of diabetes for the first time plasma glucose values ought to be reported. If anticoagulants interfere with the precipitating second antibody of double antibody insulin assay systems then separation of insulin ought to be achieved by other methods-for example, by adsorption to charcoal. They are equally efficient and simple to use.

Glucose and insulin responses are being studied under widely varying circumstances-relation between mother and fetus, hypoglycaemic disturbances in the neonate, and the effects of new oral hypoglycaemic agents. Precise comparisons of data in these and other fields cannot be made unless glucose and insulin concentrations are determined on the same basis. An agreement on basic methodology will help to save a great deal of confusion in the future.

Requests for reprints should be addressed to Dr. T. Lind, M.R.C.
Reproduction and Growth Unit, Princess Mary Maternity Hospital, Great North Road, Newcastle upon Tyne NE2 3BD.

\section{References}

Fitzgerald, M. G., and Keen, H. (1964). British Medical fournal, 1, 1568 Foster, G. L. (1923). Fournal of Biological Chemistry, 55, 291.

Grant, D. B. (1972). Lancet, 1, 207.

Henderson, J. R. (1970). Lancet, 2, 545.

Hunter, W. M. (1969). In Protein and Polypeptide Hormones, ed. M. Margoulies, I.C.S. No. 161. Amsterdam, Excerpta Medica.

Hunter, W. M., and Ganguli, P. C. (1971). In Radioimmunoassay Methods, ed. K. E. Kirkham and W. M. Hunter, p. 243. Edinburgh, Livingstone.

Lind, T., Cheyne, G. A., Billewicz, W. Z., and Fairweather, D. V. I. (1968) fournal of Obstetrics and Gynaecology of the British Commonwealth, 75, 540.

Middleton, J. E., and Griffiths, W. J. (1957). British Medical fournal, 2, 1525.

Orosz, L., Michael, R., and Ziegler, M. (1971). Lancet, 2, 1149.

Orosz, L., Michael, R., and Ziegler, M. (1971). Lancet, 2, 1149.
W.H.O. Expert Committee on Diabetes Mellitus (1965). World Health Organization. Technical Report Series, No. 310.

\title{
Infective Factors in Exacerbations of Bronchitis and Asthma
}

\author{
H. P. LAMBERT, H. STERN
}

British Medical fournal, 1972, 3, 323-327

\section{Summary}

Infections of the respiratory tract were studied in a group of families each containing a patient with chronic bronchitis or with asthma. A wide variety of infective agents may be associated with exacerbations in susceptible subjects, but the types of organism to which patients are most at risk differ according to the family structure. Exacerbations in the susceptible subject are more likely to be related to viral infections when the family contains children than when it does not.

Two patients with asthma experienced frequent respiratory infections, many of which provoked attacks of asthma.

\section{Introduction}

Attempts to assess the role of infective agents in promoting exacerbations of chronic bronchitis and other chronic respiratory diseases have given rise to widely discrepant results. Many agents have been found in association with exacerbations, but their relative importance has varied greatly in different studies. In particular, viruses have been identified with very variable frequency in several careful surveys (Somerville, 1963; Carilli et al., 1964; Eadie et al., 1966; Ross et al., 1966; Stenhouse, 1967; McNamara et al., 1969; Fisher et al., 1969). The paucity of viruses in some surveys is hard to reconcile with the common observation made in general practice that patients often have exacerbations of bronchitis when other members of the family are suffering mild, and presumably mainly viral, infection of the respiratory tract. One reason for this discrepancy may be that few studies have been made in the patient's home, and as soon

\section{St. George's Hospital, London S.W.17}

H. P. LAMBERT, M.D., F.R.C.P., Consultant Physician

St. George's Hospital Medical School, London S.W.1

H. STERN, M.B., F.R.C.PATH, Professor of Virology as possible after the onset of symptoms; viral pathogens provoking exacerbations of chronic respiratory disease might well be more difficult to identify by the time the patient has reached hospital. The family structure too, particularly the presence and age of children, might affect the chances of virus-induced exacerbations in a susceptible subject.

In the present study an attempt was made to identify infective agents implicated in provoking exacerbations of bronchitis or of asthma within the patients' households, and to study the distribution and spread of such agents in the families of these susceptible subjects. In this way it was hoped to make some estimate of the types of infective risk which "chesty" people may experience in their own homes.

\section{Methods}

Eight families, each containing at least one member with chronic bronchitis or asthma, were studied in considerable detail over an average period of two years. Each family wis visited every two weeks by a nurse specially trained in the taking of specimens, and additional visits were made if the susceptible patient developed a respiratory illness. At each visit a record card was completed for every member of the family, giving information about the following symptoms; cold, sore throat, earache, cough, sputum, wheezing, general aching, fever, diarrhoea, and vomiting. In the case of persistent symptoms, such as cough and sputum, a simple code was recorded denoting "better," "worse," or "the same." An exacerbation was defined as an increase in any two of the three symptoms of cough, sputum, and wheezing. Visits to the family doctor, or by the family doctor to the house, were also noted, together with the doctor's diagnosis.

At every visit the following specimens were taken from each member of the family: a throat swab into Stuart's transport medium for Streptococcus pyogenes, throat and nasal swabs placed together in viral transport medium, and a further throat swab which was inoculated directly into diphasic mycoplasma medium (Grayston et al., 1965). Sputum from the susceptible subjects was similarly examined for viral, mycoplasmal, and bacterial pathogens. A stool specimen for enterovirus isolation was often obtained by using containers left on the previous visit. 
Every two months, and again one to two weeks after an exacerbation in the patients, a specimen of blood was taken from the adults and older children in the family, but few blood samples were taken from the small children.

Specimens for virus isolation were inoculated within one hour of collection into primary human kidney, primary monkey kidney, and diploid human embryonic fibroblast tissue cultures. Serum specimens were examined for complement-fixing antibodies against Mycoplasma pneumoniae, Rickettsia burneti, psittacosis, herpes simplex, influenza virus types $A, B$, and $C$, parainfluenza virus types $1-3$, mumps virus, respiratory syncytial virus, and adenovirus by the microtitre method; an eightfold or greater rise in antibody level was accepted as evidence of recent infection.

The sex and age distribution of the families is shown in Table I, together with the diagnosis of the chronic respiratory illness in the susceptible subject. The Medical Research Council (1960, 1965a) shortened questionary on bronchitis was completed for

TABLE 1.-Age and Sex Composition of Eight Families, Each having a Patient with Chronic Bronchitis or Asthma

\begin{tabular}{|c|c|c|c|}
\hline \multirow{2}{*}{$\begin{array}{c}\text { Family } \\
\text { Code }\end{array}$} & \multicolumn{2}{|c|}{ Sex and Age of } & \multirow{2}{*}{ Diagnosis of Index Case } \\
\hline & $\begin{array}{r}\text { Index } \\
\text { Case }\end{array}$ & $\begin{array}{c}\text { Other Members of } \\
\text { Family }\end{array}$ & \\
\hline$\cdots$ & M. 52 & F. 49, F. 14* & $\begin{array}{l}\text { Chronic mucopurulent obstructive } \\
\text { bronchitis }\end{array}$ \\
\hline $\begin{array}{l}\cdots \\
\because \\
\cdots \\
\cdots \\
\cdots\end{array}$ & $\begin{array}{l}\text { M. } 74 \\
\text { M. } 62 \\
\text { M. } 54 \\
\text { F. } 56 \\
\text { F. } 46 \\
\text { M. } 7 * \\
\text { F. } 25\end{array}$ & $\begin{array}{l}\text { F. } 78, \text { F. } 40, \text { F. } 34 \\
\text { F. } 64 \\
\text { F. } 44, \text { F. } 76, \text { M. } 15^{*} \\
\text { M. } 62, \text { F. } 19 \\
\text { M. } 49, \text { F. 17, F. } 16 \\
\text { M. 34, F. 30, F. } 3 \\
\text { M. 27, F. 6, F. } 2 / 12\end{array}$ & 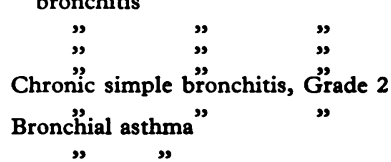 \\
\hline
\end{tabular}

- At school.

each of the patients and measurements were made of vital capacity and peak flow. Two additional families were studied by serial record cards and serum antibody profile, but available facilities did not allow regular attempts at viral isolation from them. Results which include data from these additional families are indicated in the text. The families were recruited at short intervals and each remained under detailed study for two years. For some of the families serial specimens of serum were obtained during a third year.

\section{Results}

The infective agents recognized in eight patients with chronic bronchitis or asthma during periods of illness and during routine two-weekly visits is shown in Table II. An infective

TABLE II-Incidence of Infective Agents Recognized in Eight Patients with TABLE II-Incidence of Infective Agents Recognized in Eight Patients with of Respiratory Illness

\begin{tabular}{|c|c|c|c|c|c|c|c|}
\hline \multirow{2}{*}{$\begin{array}{l}\text { Reason for } \\
\text { Visit to } \\
\text { Patients }\end{array}$} & \multicolumn{2}{|c|}{\begin{tabular}{|l} 
Six Patients with \\
Chronic Bronchitis
\end{tabular}} & \multicolumn{2}{|c|}{$\begin{array}{l}\text { Two Patients } \\
\text { with Asthma }\end{array}$} & \multicolumn{2}{|c|}{ Total } & \multirow{2}{*}{$\begin{array}{l}\text { Percentage } \\
\text { of Visits in } \\
\text { which } \\
\text { Infective } \\
\text { Agents } \\
\text { were } \\
\text { Detected }\end{array}$} \\
\hline & $\begin{array}{l}\text { No. of } \\
\text { Visits }\end{array}$ & $\begin{array}{c}\text { No. of } \\
\text { Infective } \\
\text { Agents } \\
\text { Detected }\end{array}$ & $\begin{array}{l}\text { No. of } \\
\text { Visits }\end{array}$ & $\begin{array}{l}\text { No. of } \\
\text { Infective } \\
\text { Agents } \\
\text { Detected }\end{array}$ & $\begin{array}{l}\text { No. of } \\
\text { Visits }\end{array}$ & $\begin{array}{l}\text { No. of } \\
\text { Infective } \\
\text { Agents } \\
\text { Detected }\end{array}$ & \\
\hline $\begin{array}{l}\text { Routine } \\
\text { Acute exac- } \\
\text { erbation of } \\
\text { bronchitis } \\
\text { or asthma } \\
\text { Other respir- } \\
\text { atory illness }\end{array}$ & $\begin{array}{l}30 \\
10\end{array}$ & $\begin{array}{r}13 \\
1\end{array}$ & $\begin{array}{l}11 \\
22\end{array}$ & $\begin{array}{l}6 \\
9\end{array}$ & $\begin{array}{l}41 \\
32\end{array}$ & $\begin{array}{l}19 \\
10\end{array}$ & $\begin{array}{l}46 \\
31\end{array}$ \\
\hline
\end{tabular}

agent was found in 19 out of $41(46 \%)$ exacerbations and in 10 out of $32(31 \%)$ other respiratory illnesses-namely, colds, sore throats, etc., which did not progress to exacerbations. By contrast, infective agents were found on only 13 out of 332 $(4 \%)$ routine visits.

The variety of bacteria and viruses associated with an exacerbation of bronchitis, or with the development of acute asthma, is shown in Table III. The illnesses were characteristic exacerbations of bronchitis or acute attacks of asthma, and infections caused by different agents were generally indistinguishable from one another on clinical grounds. The single exacerbation associated with infection by $R$. burneti ( $Q$ fever) followed a farm holiday in Scotland.

TABLE III-Incidence and Nature of Infective Agents Recognized during Exacerbations in Six Patients with Chronic Bronchitis and Two Patients with Asthma

\begin{tabular}{|c|c|c|c|}
\hline \multirow{2}{*}{$\begin{array}{l}\text { Family } \\
\text { Code }\end{array}$} & \multicolumn{2}{|c|}{ Exacerbations } & \multirow{2}{*}{ Agents Identified } \\
\hline & $\begin{array}{l}\text { Total } \\
\text { No. }\end{array}$ & $\begin{array}{c}\text { Agent } \\
\text { Recognized }\end{array}$ & \\
\hline
\end{tabular}

\begin{tabular}{|c|c|c|c|c|}
\hline \multicolumn{5}{|c|}{ Patients with Chronic Bronchitis } \\
\hline $\begin{array}{l}\text { A } \\
\text { D }\end{array}$ & $\begin{array}{l}\ldots \\
\ldots\end{array}$ & $\begin{array}{l}6 \\
5\end{array}$ & $\begin{array}{l}3 \\
4\end{array}$ & \multirow{2}{*}{$\begin{array}{l}\text { Parainfluenza virus } 1 \text { (twice). R. burneti } \\
\text { H. influenzae. Staph. pyogenes. Str. pneumoniae } \\
\text { Parainfluenza virus } 3 \text {. } \\
\text { Str. pneumoniae. Parainfluenza virus } 3 \\
\text { R.S. virus. Parainfluenza virus } 1 \\
\text { Psittacosis } \\
\text { Rhinovirus H }\end{array}$} \\
\hline $\begin{array}{l}\mathbf{E} \\
\mathbf{F} \\
\mathbf{G} \\
\mathbf{J}\end{array}$ & $\begin{array}{l}\cdots \\
\cdots \\
\cdots\end{array}$ & $\begin{array}{l}6 \\
6 \\
4 \\
3\end{array}$ & $\begin{array}{l}2 \\
2 \\
1 \\
1\end{array}$ & \\
\hline \multicolumn{5}{|r|}{ Patients with Asthma } \\
\hline B & . & 5 & 3 & \multirow{2}{*}{$\begin{array}{l}\text { Rhinovirus } M+\text { parainfluenza virus } 1 \text {. Rhinovirus } \\
\text { H. Adenovirus type } 1 \\
\begin{array}{l}\text { H. influenzae. Parainfluenza virus } \\
\text { H. Rhinovirus } \\
\text { Str. pneumoniae }\end{array}\end{array}$} \\
\hline C & . & 6 & 3 & \\
\hline
\end{tabular}

Infective agents identified in 10 out of 32 respiratory illnes. s unassociated with exacerbations of chronic bronchitis or asthma are listed in Table IV. Agents were also identified on $13 \mathrm{oc}$. casions without associated illness. These included isolations of influenza virus B, herpesvirus hominis, Str. pneumoniae, and poliovirus (vaccine strain), and serological evidence of infection

TABLE IV-Incidence and Nature of Infective Agents Recognized in Eight Patients with Chronic Bronchitis or Asthma during Episodes of Mild Respiratory Illness

\begin{tabular}{|c|c|c|c|c|}
\hline Patients & $\begin{array}{c}\text { No. of } \\
\text { Illnnsses }\end{array}$ & $\begin{array}{l}\text { No. in } \\
\text { which } \\
\text { an Agent } \\
\text { was } \\
\text { Recog- } \\
\text { nized }\end{array}$ & $\begin{array}{c}\text { Isolation or Isolation }+ \\
\text { Serology }\end{array}$ & Serology \\
\hline $\begin{array}{l}6 \text { patients with } \\
\text { chronic bronchitis } \\
2 \text { patients with } \\
\text { asthma }\end{array}$ & 10 & 9 & $\begin{array}{l}\text { Str. pyogenes (twice) } \\
\text { Infiuenza virus A and } \\
\text { Str. pneumoniae } \\
\text { Parainfluenza virus } 4 a \text { and } \\
\text { H. influenzae } \\
\text { Coxsackie virus type B3 }\end{array}$ & $\begin{array}{l}\text { Adenovirus } \\
\text { R.S. virus } \\
\text { Adenovrus } \\
\text { M. pneu- } \\
\text { moniae } \\
\text { Mumps virus }\end{array}$ \\
\hline
\end{tabular}

TABLE V-Methods by which Viral Infections were Detected in the Eight Susceptible Patients

\begin{tabular}{|c|c|c|c|c|}
\hline \multirow{2}{*}{ Agent } & \multicolumn{3}{|c|}{ No. of Isolations from } & \multirow{2}{*}{$\begin{array}{l}\text { No. Diagnosed } \\
\text { by Serology } \\
\text { Only }\end{array}$} \\
\hline & Sputum & $\begin{array}{c}\text { Nose and } \\
\text { Throat Swab }\end{array}$ & Stool & \\
\hline 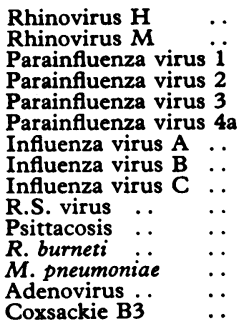 & $\begin{array}{l}3 \\
1 \\
2 \\
0 \\
1 \\
1 \\
1 \\
0 \\
0\end{array}$ & $\begin{array}{l}0 \\
0 \\
1 \\
0 \\
0 \\
0 \\
1 \\
0 \\
0 \\
0\end{array}$ & $\begin{array}{l}1 \\
1\end{array}$ & $\begin{array}{l}2 \\
3 \\
1 \\
1 \\
1 \\
3\end{array}$ \\
\hline Total & 9 & 2 & 2 & 19 \\
\hline
\end{tabular}


with influenza viruses $B$ and $C$, parainfluenza virus 2 and 3, respiratory syncytial virus, and adenovirus; some of them on two occasions. Again, a wide variety of agents was found both on routine visits and in association with minor respiratory illness. Double infections with a pathogenic bacterium and a virus were identified three times and on another occasion two respiratory viruses were isolated at the same time.

The methods contributing to diagnosis of the respiratory viral infections in the susceptible subjects are shown in Table V. The value of sputum as a source for virus isolation is strikingly evident.

\section{FAMILY STRUCTURE AND VIRAL INFECTION}

Respiratory infection is more common in children than in adults, and among adults those who are in contact with children suffer more infections than those who are not. This relation of family structure to the clinical syndromes of respiratory infection was clearly shown in the Cleveland Survey (Badger et al., 1953) and was also apparent in the present study. Thus, excluding the susceptible index members of the families, viruses and pathogenic bacteria were isolated on 14 occasions from five school or preschool children (including rhinovirus, herpes simplex, parainfluenza virus 1 twice, adenovirus twice, Coxsackie B3 virus twice, vaccine poliomyelitis virus, and Str. pyogenes twice) as compared with only seven isolations (parainfluenza virus 1 twice and Str. pyogenes five times) from 14 adults. In Table VI viral infections in adult members of the families which included

TABLE VI-Frequency of Virus Infection in Adult Members of Families with and without Schoolchildren

\begin{tabular}{c|c|c|c|c|c|c}
\hline & \multirow{2}{*}{ Families } & \multicolumn{2}{|c|}{$\begin{array}{c}\text { No. of Illnesses } \\
\text { Adults }\end{array}$} & \multicolumn{2}{|c|}{$\begin{array}{c}\text { No. of Subclinical } \\
\text { Infections } \\
\text { Diagnosed by }\end{array}$} & $\begin{array}{c}\text { Total No. of } \\
\text { Infections }\end{array}$ \\
\cline { 2 - 5 } & Isolation & $\begin{array}{c}\text { Serology } \\
\text { Only }\end{array}$ & Isolation & $\begin{array}{c}\text { Serology } \\
\text { Only }\end{array}$ & \\
\hline $\begin{array}{c}\text { With school and/or } \\
\text { preschool children } \\
\text { Without school or } \\
\text { preschool children }\end{array}$ & 9 & 7 & 7 & $* 1$ & 14 & 28 \\
\hline
\end{tabular}

- Herpes simplex virus; not included in total.

children are compared with infections in the adult-only families. Evidence of clinical or subclinical viral infection was obtained on 28 occasions in nine adults belonging to families which included children but on only 11 occasions in the 13 members of adult-only families.

The effect of family structure on the impact of respiratory illness is also shown by noting the spread of infection in families with and without schoolchildren. Illnesses with family spread were defined as those in which a respiratory infection was recorded in more than one member of the family on the same or on a proximate visit, following a record of normal health on the preceding visit. Two families containing asthmatic patients were excluded from this comparison, since both susceptible subjects were young, 7 and 25 years respectively, and their inclusion would have invalidated this comparison. The two additional families not listed in Table I, who were studied by serial record cards and serum profiles only, were, however, included. We were able in this way to compare four families with and four families without schoolchildren. Transmission within the family was noted in $31 \%$ of the respiratory illnesses (17 out of 55 ) in the families with schoolchildren, but in only $18 \%$ (12 out of 68) of the respiratory illnesses in the families without schoolchildren. This difference does not, however, achieve the conventional level of significance $(0.05>\mathrm{P}>0.01)$.

\section{RESPIRATORY PATHOGENS AND SUSCEPTIBILITY}

Several bacterial, mycoplasmal, and viral infections were identified in the healthy family members, some associated with respiratory illnesses and others causing subclinical infection. Infections in the healthy contacts are not analysed fully in this paper, but they do provide vivid illustrations both of the general frequency of respiratory pathogens and of the varied effects of the same pathogen, acting at the same time, on subjects of different susceptibility. Three examples may be cited.

A girl aged 14 developed a runny nose and sore throat and parainfluenza virus 1 was isolated from the throat swab. Her serum antibody titre to this virus rose from 8 to 256 . Two weeks later her father, a patient with chronic bronchitis, developed a severe exacerbation. Parainfluenza virus 1 was isolated from his sputum. The mother remained entirely well but her serum antibody titre against parainfluenza virus 1 rose from $<8$ to 32 .

An asthmatic child aged 7 developed a typical severe attack of asthma. Parainfluenza virus 1 and a rhinovirus $M$ were isolated from his sputum. The parinfluenza virus 1 was also isolated from his father and from his 3-year-old sister who both remained well.

The same child developed an attack of asthma. Adenovirus type 1 was isolated from his stool and his serum antibody level against this virus rose from 8 to 128 . His 3-year-old sister was found to have the virus in her throat and faeces and her antibody level rose from $<8$ to $>512$; she remained perfectly well.

\section{ANTIBODY TO STR. PNEUMONIAE AND TO H. INFLUENZAE}

All sera collected in the study were examined for antibody to these bacteria by Professor J. R. May at the Institute of Diseases of the Chest. The sera were tested by the double-diffusion method against both antigens. Sera showing reactions to the haemophilus extract, which contains both specific and cross-reacting antigens, were re-examined by immunoelectrophoresis in order to detect specific antibody against $H$. influenzae (Burns and May, 1967; Burns, 1968). Some patients' sera regularly contained antibody to one or other or both antigens, and there was no evident correlation between this finding and the subjects' clinical state or liability to respiratory infections. On six occasions individuals previously without antibody developed specific antibody to one or other of the bacteria. These reactions are summarized in Table VII together with a comment on the clinical events associated in time with the antibody rise.

TABLE VII-Illnesses Associated with Development of Serum Antibody to Str. pneumoniae and $\mathrm{H}$. influenzae in Two Patients with Chronic Bronchitis and Four Healthy Subjects

\begin{tabular}{|c|c|c|c|c|c|}
\hline & $\begin{array}{l}\text { mily } \\
\text { code }\end{array}$ & Sex & Age & $\begin{array}{l}\text { Development of } \\
\text { Antibody against }\end{array}$ & Associated Illness \\
\hline \multicolumn{6}{|c|}{ Susceptible subjects } \\
\hline \multirow{2}{*}{$\underset{\mathbf{E}}{\mathbf{D}}$} & .. & \multirow{2}{*}{$\begin{array}{l}\text { M. } \\
\text { F. }\end{array}$} & \multirow{2}{*}{$\begin{array}{l}74 \\
56\end{array}$} & Str. pneumoniae & Exacerbation of bronchitis \\
\hline & . & & & $" \quad \Rightarrow$ & " \\
\hline \multicolumn{6}{|c|}{ Normal Subjects } \\
\hline $\begin{array}{l}\mathbf{A} \\
\mathbf{H} \\
\mathbf{G} \\
\mathbf{G}\end{array}$ & $\begin{array}{l}\cdots \\
\cdots \\
\cdots\end{array}$ & $\begin{array}{l}\text { F. } \\
\text { F. } \\
\text { F. }\end{array}$ & $\begin{array}{l}49 \\
14 \\
49 \\
16\end{array}$ & $\begin{array}{l}\text { Str. pneumoniae } \\
\text { H. influenzae } \\
\text { " }\end{array}$ & $\begin{array}{l}\text { Cold } 12 \text { days previously } \\
\text { Sore throat } 5 \text { days previously } \\
\text { Cold and bronchitis } \\
\text { Cold } 1 \text { week previously }\end{array}$ \\
\hline
\end{tabular}

\section{Discussion}

The role of viruses in provoking exacerbation of bronchitis has proved difficult to evaluate, partly because reliable techniques for isolation of respiratory viruses have only in recent years become available, and partly because patients have often been investigated after admission to hospital, many days after their initial symptoms, when it might no longer be possible to recover a virus provocative of the initial illness.

Nevertheless, clear evidence has emerged that a number of viruses, some of them of low pathogenicity for the healthy adult, may cause exacerbations of bronchitis, and that in chronic 
bronchitic patients these viruses are more likely to cause an exacerbation than the simple upper respiratory tract symptoms characteristic of infection in healthy individuals. The role of rhinoviruses has been especially well documented. Stenhouse (1967) cultivated rhinoviruses from 8 out of 56 exacerbations in 34 patients with chronic bronchitis $(14 \%)$ but from only 5 out of 237 specimens taken during quiescent phases $(2 \cdot 1 \%)$. He stressed that patients with chronic bronchitis present during rhinovirus infection with typical exacerbations, which may or may not be accompanied by upper respiratory symptoms, whereas control patients without bronchitis develop rhinorrhoea with or without fever. Eadie et al. (1966) also showed the importance of rhinoviruses which they found in 11 out of $47(23 \%)$ illnesses affecting the chest in 15 subjects with chronic bronchitis. Their study combined with a larger serological investigation of bronchitics and matched controls (Ross et al., 1966) suggested that viruses were responsible for 20 out of $125(16 \%)$ exacerbations.

Our study, too, showed a relatively rich yield of viral causes of acute illness in susceptible subjects, since evidence of coincident viral infection was found in 8 out of $30(27 \%)$ exacerbations of bronchitis and in 5 out of $11(45 \%)$ exacerbations of asthma, an overall incidence of $34 \%$. This yield was obtained despite using a stricter criterion for serological evidence of infection than the conventional fourfold rise. We chose the criterion of an eightfold rise because, reviewing our collections of two-monthly sera from each adult patient over a period of two to three years, it was common to observe fluctuations of antibody titre of as much as fourfold, although the sera were tested simultaneously and with strictly controlled technique. Many of these fluctuations over the course of months could not be related to clinical syndromes so we preferred the more rigorous criterion of an eightfold rise as evidence of infection.

By contrast, a thorough study by Fisher et al. (1969), which included a careful search for viral and mycoplasmal as well as bacterial agents, gave a relatively scanty yield of viruses. Evidence of viral infection by the conventional fourfold rise in antibody titre was found in 7 out of 63 exacerbations, with serological evidence of $M$. pneumoniae on two more occasions, but only two significant viral isolations were made-one of influenza $B$ and one of a rhinovirus. In the study of Fisher et al., as in Eadie's and our own, the patients were visited in their own homes as soon as possible after the onset of an exacerbation, so that differences in viral isolation cannot be ascribed to delay in acquiring the specimens. The contrast between Fisher's study and our own is the more striking since our methods for rhinovirus isolation were probably less than optimal, and we may well have underestimated the true number of rhinovirus-provoked exacerbations.

\section{FAMILY STRUCTURE}

It is likely that some of these notable differences between the results of apparently comparable studies can be attributed to the structure of the families of the susceptible subjects. In Fisher's investigation 18 of the 23 patients were in households containing adults only, and "young family contacts were rare," whereas in the study of Eadie et al. (1966) with its rich yield of rhinoviruses, 16 of the 41 contacts were less than 10 years old; the bronchitics from whom rhinoviruses were isolated were younger, and had more young family contacts, than those from whom rhinoviruses were not isolated.

The relative ease with which viruses may be isolated from children as compared with adults is well known, and it is evident that this greater prevalence of virus infection extends to adult members of families containing children. The Medical Research Council (1965b) survey of respiratory infections showed a preponderance of small children in households in which respiratory syncytial virus, parainfluenza virus, and adenoviruses types 1,2 , and 5 were found. Our study of infective risks to susceptible subjects within their family setting again shows the prevalence of viruses in children, and in their adult contacts. Evidence of viral infection by isolation or serology or both was obtained much more commonly in adult members of families with children than in adult only households (Table VI). Viruses were isolated 12 times in non-susceptible children, but only twice in non-susceptible adults, and it is likely that subjects from whom viruses are isolated contribute a greater infective risk than those in whom the evidence of viral infection is based only on seralogical findings.

It seems that the nature and number of infections which put a susceptible subject at risk of exacerbation differ significantly according to his family situation. In families consisting only of adults bacterial causes may be most important; Fisher et al. (1969) found pneumococci and/or H. influenzae in $32 \%$ of their exacerbations, and showed that these organisms were found with significantly greater frequency during exacerbations than during quiescence. Susceptible patients in families containing preschool and school children may be at greater risk from the common respiratory viruses. Indeed, a remarkable variety of agents has now been shown to provoke exacerbations of chronic chest illness in susceptible subjects, including, in our study, most of the known respiratory pathogens.

The provocation of asthmatic attacks by viral infection has seldom been documented, and the high prevalence of such infection in our two asthmatic patients is notable. One of them was a young adult with two small children, the other was a child with a younger sibling, and both were in contact with very frequent episodes of respiratory illness. For example, the sister of the asthmatic child, herself a healthy child aged 3 at the beginning of the study, experienced 12 clinical respiratory illnesses in the two years of observation, in addition to mumps and rubella. Three of the illnesses could be assigned to specific agents, and another three subclinical infections were detected, involving Str. pyogenes, Coxsackie virus type B3, and herpes simplex, giving a total of 17 infections in two years. Young asthmatic patients may thus be exposed to very frequent infective risks from their family contacts.

This evidence of special risks to susceptible patients in contact with young children carries implications for future immunization programmes, since estimates of the likely value of new vaccines will need to take into account the family setting of susceptible patients for whom they may be used.

The value of sputum as a source of respiratory viruses, though not generally known, is evident from Table $\mathrm{V}$ and emerges also from other studies. Eadie et al. (1966) grew rhinoviruses from the sputum on five occasions, in three of which the throat swab was negative, and Stenhouse (1967) found the sputum contained a rhinovirus on two occasions when the throat swab did not.

Finally we would again emphasize two points made by Fisher et al. (1969). First, in studies of bronchitis, definitions of the word "exacerbation" vary greatly and a generally useful definition is hard to devise. It is therefore difficult to compare the findings of different workers. Second, the amount of work involved in this type of study is considerable, so that the number of patients and families studied by any one team of investigators is necessarily limited. We agree that the suggestions raised by this type of work can be confirmed and extended only by collaborative studies on a larger scale.

We are indebted to Drs. T. Williamson, G. Sharpe, N. Barley, and B. Raeburn, general practitioners in South-west London. The study was conducted in their practice with their enthusiastic collaboration and the specimens were processed in a branch laboratory established within their health centre. We acknowledge also expert technical help from Miss Diana Hawkesworth and Mrs. Mary Creasey. Our thanks are due to the Board of Governors, St. George's Hospital, for a grant in support of this project.

\section{References}

Badger, G. F., et al. (1953). American fournal of Hygiene, 58, 174 Burns, M. W. (1968). Lancet, 1, 223. 
Burns, M. W., and May, J. R. (1967). Lancet, 1, 354.

Carilli, A. D., Gohd, R. S., and Gordon, W. (1964). New England fournal of Medicine, 270, 123 .

Eadie, M. D., Stott, E. J., and Grist, N. R. (1966). British Medical fournal, 2, 671.

Fisher, M., et al. (1969). British Medical fournal, 4, 187.

Grayston, J. T., et al. (1965). Fournal of the American Medical Association, 191, 369 .
McNamara, M. J., Phillips, I. A., and Williams, O. B. (1969). American Review of Respiratory Diseases, 100, 19

Medical Research Council (1960). British Medical fournal, 2, 1665.

Medical Research Council (1965a). Lancet, 1, 775.

Medical Research Council (1965b). British Medical fournal, 2, 319.

Ross, C. A., et al. (1966). Thorax, 21, 461.

Somerville, R. G. (1963). Lancet, 2, 1247 .

Stenhouse, A. C. (1967). British Medical fournal, 3, 461.

\title{
Creatine Phosphokinase Activity during Lithium Treatment
}

\author{
R. GOSLING， R. J. KERRY， G. OWEN
}

British Medical fournal, 1972, 3, 327-329

Patients and Methods

All patients attending the Northern General Hospital lithium clinic had been previously diagnosed as suffering from manic depressive illness and suitable for treatment with prophylactic lithium. Patients did not receive any other medication and attended the clinic at regular intervals for clinical and biochemical assessment. These patients have been known to one of us (R.J.K.) for up to 10 years and their psychiatric history has been well documented both before and after starting lithium treatment.

Clinicians forwarding sera from their own patients were consulted about the clinical state of the patient and the nature of the illness. They confirmed that the patients were not receiving any other psychotrophic drugs.

\section{SERUM LITHIUM ESTIMATIONS}

\section{Introduction}

The value of lithium in the treatment of mania is established, but its prophylactic use in mania and depression is still a matter of dispute. The natural history of manic depressive illness with its long periods of remission have prompted Blackwell and Shepherd (1968) to question the prophylactic action of lithium. Long symptom-free periods on lithium carbonate may be due either to the prophylactic action of the lithium ion or to a long period of remission in the disease.

Creatine phosphokinase (C.P.K.) activity has been shown to be increased during some acute episodes of psychotic illness (Meltzer, Elkun, and Moline, 1969). We have confirmed these changes in about half of a group of acutely psychotic patients (Gosling, Kerry, Orme, and Owen, 1972).

Since 1964 a special lithium clinic for the supervision of patients considered suitable for treatment with lithium carbonate has been run at this hospital. These patients attend at appropriate intervals for clinical assessment and the estimation of their serum lithium concentration. In addition, a large number of sera are referred from other clinics in the Sheffield region for serum lithium measurement.

In view of the association between psychotic illness and increased C.P.K. activity it was decided to (1) measure the C.P.K. activity in all blood samples taken for serum lithium estimation in our clinic, and (2) to measure the C.P.K. activity in all serum samples referred to us for serum lithium estimation from other clinics. These repeated estimations give us an opportunity of seeing if lithium stabilizes C.P.K. activity as well as mood.

\footnotetext{
Department of Chemical Pathology, Northern General Hospital, Sheffield

R. GOSLING, B.SC., Biochemist

R. J. KERRY. M.R.C.S., L.R.C.P., D.P.M., Consultant Psychiatrist

G. OWEN, M.B., F.R.C.PATH., Consultant Chemical Pathologist
}

Serum lithium concentrations were measured by atomic absorption with an E.E.L. 140 atomic absorption spectrophotometer and a lithium specific lamp. All sera were obtained from venous blood collected in plain glass universal containers. These sera were diluted 1 in 5 with distilled water. They were compared with appropriate standards prepared from a lithium reference standard supplied by the Fisher Corporation.

\section{SERUM CREATINE PHOSPHOKINASE MEASUREMENTS}

The C.P.K. activity at $35^{\circ} \mathrm{C}$ was estimated by linking the C.P.K. catalysed reaction through hexokinase to one involving glucose6-phosphate dehydrogenase and the conversion of nicotinamide adenine dinucleotide phosphate to its reduced form. Glutathione was included within the reaction mixture to "activate" the C.P.K. The increase in optical density at 340 nanometres due to the formation of the reduced nicotinamide adenine dinucleotide phosphate was plotted by using an L.K.B. 8600 reaction rate analyser and is directly proportional to the C.P.K. activity.

To ascertain the effect, if any, of the lithium ion on the estimation of C.P.K. pooled human serum with raised C.P.K. activity was divided into two portions. One portion was seeded with lithium carbonate to establish a prophylactic serum lithium concentration of $2 \mathrm{mEq} / \mathrm{l}$. Comparison between the seeded and non-seeded sera showed that a prophylactic lithium concentration does not interfere with the estimation of C.P.K.

The reagents used were supplied by the Boehringer Corporation in the form of a test kit for C.P.K. determination (Cat. No. 15926. TCAF). Solutions were prepared as recommended by Boehringer and the reaction was started by the automatic addition by the L.K.B. 8600 of $75 \mu$ l of creatine phosphate, solution 3 of the assay system. For all the solutions only half the recommended test quantities were used because the L.K.B. 